\title{
Profiling spermatogenic failure in adult testes bearing Sox9-deficient Sertoli cells identifies genes involved in feminization, inflammation and stress
}

\author{
Aurélie Lardenois ${ }^{1}$, Frédéric Chalmel ${ }^{1}$, Francisco Barrionuevo ${ }^{2,4}$, Philippe Demougin ${ }^{3}$, Gerd Scherer $^{2}$, \\ Michael Primig ${ }^{1 *}$
}

\begin{abstract}
Background: Sox9 (Sry box containing gene 9) is a DNA-binding transcription factor involved in chondrocyte development and sex determination. The protein's absence in testicular Sertoli nurse cells has been shown to disrupt testicular function in adults but little is known at the genome-wide level about molecular events concomitant with testicular break-down.

Methods: To determine the genome-wide effect on mRNA concentrations triggered by the absence of Sox9 in Sertoli cells we analysed adult testicular tissue from wild-type versus mutant mice with high-density oligonucleotide microarrays and integrated the output of this experiment with regulatory motif predictions and protein-protein network data.

Results: We report the genome-wide mRNA signature of adult testes lacking Sox9 in Sertoli cells before and after the onset of late spermatogenic failure as compared to fertile controls. The GeneChip data integrated with evolutionarily conserved Sox9 DNA binding motifs and regulatory network data identified genes involved in feminization, stress response and inflammation.

Conclusions: Our results extend previous observations that genes required for female gonadogenesis are upregulated in the absence of Sox9 in fetal Sertoli cells to the adult stage. Importantly, we identify gene networks involved in immunological processes and stress response which is reminiscent of a phenomenon occurring in a sub-group of infertile men. This suggests mice lacking Sox9 in their Sertoli cells to be a potentially useful model for adult human testicular failure.
\end{abstract}

\section{Background}

Sex differentiation of mammalian males is controlled by the Y-chromosomal locus Sry (Sex-determining region of Y-chromosome) which, in cooperation with Steroidogenic factor 1 (Sf1), directly activates the expression of Sox9 [1]; for review, see [2]. This protein is an important transcription factor involved in various developmental processes and pathologies [3]. Sox9 is expressed in supporting cell precursors destined to become Sertoli cells which are required for normal testis morphology and germ cell development [4-6]; reviewed in $[7,8]$. Sox9 is actively imported into the nucleus during male gonad

\footnotetext{
* Correspondence: michael.primig@inserm.fr

${ }^{1}$ Inserm, U625, Université de Rennes 1, IFR140, Rennes, F-35042, France Full list of author information is available at the end of the article
}

development $[9,10]$ and specifically interacts with the $\mathrm{A} / \mathrm{TCAA}_{\mathrm{T}}^{\mathrm{T}} / \mathrm{A}$ motif via its high mobility group (HMG) DNA binding and DNA bending domain $[2,11]$. The protein is thought to stimulate its own expression via a C-terminal transactivation domain together with $S f 1$ after the sex determination stage when Sry expression is repressed; reviewed in $[2,12]$.

Human SOX9 was found to be mutated in patients suffering from campomelic dysplasia, a condition linked with abnormal skeletal development and, critically, perturbed male gonadogenesis or complete sex reversal $[13,14]$. This is in keeping with an important role for the rodent Sox9 protein in murine male gonad development initially suggested on the basis of its expression pattern $[5,6]$. Experiments addressing Sox9's reproductive

\section{C) Biomed Central}


function were complicated by the fact that homozygous constitutive mutant mouse embryos die before the onset of sex differentiation [15]. Therefore, earlier work demonstrating the protein's critical role in the process of pre-natal testis development was based on Sertoli cellspecific partial or complete ablation of Sox9 in the mouse embryo prior to the initial stage of testis development $[16,17]$. Recently it was reported that Sertoli-cell specific deletion of Sox9 at embryonic day 14 (E14.0) - two and a half days after the sex determination stage - had no effect on the formation of seminiferous tubules and early adult testicular function; however, at late stages testicular architecture and spermatogenesis were disrupted [18]. These results suggest critical roles for Sox 9 during prenatal sex determination and in adult maintenance of spermatogenesis. However, nothing is known about the global impact of Sox9's absence in adult Sertoli cells at the molecular level [19].

Here we investigate the testicular genome-wide mRNA concentration profile in adult mice bearing an AMHCre transgene and two Sox 9 alleles with Cre recognition sites (AMH-Cre Sox $9^{\text {flox/flox }}$ ). Testicular samples from mice whose Sertoli-cells lack Sox9 from E14.0 onwards were isolated before the onset of infertility at the age of 90 days post partum (dpp) and at $165 \mathrm{dpp}$, when the phenotype was clearly detectable. These samples were compared to controls homozygous for a functional Sox 9 allele $\left(\operatorname{Sox} 9^{\text {flox/flox }}\right)$ taken at the same age. The output of the expression profiling study was integrated with a genome-wide search for evolutionarily conserved Sox9 binding sites to help identify potential direct targets and with regulatory network data to explore systemic effects in the mutant. Our results reveal a complex mRNA signature in part due to changing testicular cell proportions and to the up-regulation of genes involved in female gonad development but also possibly to the de-regulation of mouse genes involved in stress response and inflammation not previously reported in the context of spermatogenic failure.

\section{Methods}

Mouse strains

Mice bearing Sox $9^{\text {flox/flox }}$ [20] and AMH-Cre transgenes [21] were crossed to obtain AMH-Cre Sox $9^{\text {flox/flox }}$ mice which were genotyped as published [18].

\section{Testicular sample preparation}

Total testis samples were prepared from C57BL/6 Sox9flox/flox and AMH-Cre Sox $9^{\text {flox/flox }}$ mutant animals at 3 (90 dpp) and 5.5 (165 dpp) month after birth. Testes of at least three animals for each time points were decapsulated and combined into duplicate pools using standard laboratory practice.

\section{Target synthesis, GeneChip hybridization and raw data production}

Total RNA preparation, cRNA target synthesis and raw data production using Mouse Genome 430 2.0 GeneChips (Affymetrix) were essentially done as previously published [22].

\section{Expression data analysis}

The microarray data were pre-processed and analyzed using the AMEN (Annotation, Mapping, Expression and Network analysis) suite of tools [23]. The data quality was verified by plotting the surface intensity distribution, 3'-5' RNA degradation and $\log 2$ signal distribution across samples. Data were normalized using the Robust Multi-Array Average (RMA) method as previously published and the global signal intensities from $\operatorname{Sox} 9^{\text {flox/flox }}$ and mutant AMH-Cre Sox $9^{\text {flox/flox }}$ samples were visualized using a Distance Matrix in combination with a dendrogram as published [22,24].

\section{Statistical filtration and classification}

Probe sets yielding a signal higher than the detection threshold (median of the normalized dataset, cutoff 5.3) and a fold-change $\geq 2.0$ between $\operatorname{Sox} 9^{\text {flox/flox }}$ and AMHCre $\operatorname{Sox} 9^{\text {flox/flox }}$ at 90 and $165 \mathrm{dpp}$ were selected. A LIMMA statistical test (F-value adjusted with the False Discovery Rate method: $\mathrm{p} \leq 0.01$ ) was employed to identify significantly differentially expressed probe sets which were subsequently classified into two groups using the $\mathrm{k}$-means algorithm $(\mathrm{k}=2)$.

\section{Gene Ontology (GO) and transcription factor binding site (TFBS) enrichment}

Enrichment of GO terms and predicted TFBSs were estimated with the Fisher exact probability using a Gaussian Hypergeometric test as previously published [22]. A GO term or a TFBS matrix was considered to be significantly enriched in a group of genes when the FDR-corrected $p$-value was $\leq 0.01$ and the number of genes bearing this annotation or a TFBS was $\geq 5$.

\section{Regulatory network analysis}

The network representation was drawn using AMEN [23]. The protein-gene regulation data were downloaded from the TRANSFAC Professional Database release 2010.1 [25] and from Transcription Factor Encyclopedia (TFe, accessed May $1^{\text {st }}, 2010$ ).

\section{Prediction of TFBSs conserved across species}

Transcriptional Start Sites (TSS) extracted from all_mrna. txt and refseqAli.txt UCSC mapping files were localized by associating annotated mouse protein-coding genes ( $\mathrm{mm} 9$ genome) with their corresponding transcripts as defined in 
the gene2accession file provided by the NCBI [26]. TFBSs matrices from the TRANSFAC Professional Database release 2010.1 were predicted using the MATCH software [27] with the minSUM_good profile to minimize false negative and false positive predictions. Motif predictions were limited to a region of $1 \mathrm{~kb}$ upstream of the Transcriptional Start Site (TSS). Motifs displaying a core similarity score (CSS) and a matrix similarity score (MSS) of $\geq 0.8$ were selected. To further reduce the number of false positives potential motifs had to be conserved [28]. For each prediction a cross-species conservation score was computed by averaging the base-by-base phastCons scores calculated between 30 vertebrates as provided by the UCSC genome browser [29]. Predicted motifs with a conservation score $\geq 0.8$ were selected. Mouse genes whose promoters contained at least one predicted motif were used to calculate its enrichment as compared to the promoters of all annotated genes.

\section{MIAME Compliance}

Raw data CEL files corresponding to 8 total testicular samples collected in duplicate at the age of 90 and $165 \mathrm{dpp}$ from C57BL/6 Sox $9^{\text {flox/flox }}$ and AMH-Cre Sox $9^{\text {flox/flox }}$ mice, respectively, are available via the EBI's ArrayExpress under the accession number E-TABM-528 [30]. Normalized data are available for viewing at GermOnline [31].

\section{Results}

\section{Experimental design and quality control}

It was found earlier that Sertoli-cell specific deletion of Sox9 from E14 onwards had no effect on the fertility of young adults but caused late spermatogenic failure due to progressive degeneration of the seminiferous tubules [18]. To gain insight into which Sox9-dependent processes may contribute to this phenotype we compared the testicular mRNA profiles of phenotypically normal Sox $9^{\text {flox/flox }}$ mice and mutant AMH-Cre $\operatorname{Sox} 9^{\text {flox/flox }}$ mice. As a control, samples from both backgrounds were first taken at $90 \mathrm{dpp}$ prior to the onset of the phenotype where testes from Sox $9^{\text {flox/flox }}$ and AMH-Cre Sox $9^{\text {flox/flox }}$ mice are morphologically and histologically indistinguishable. A second set of samples was prepared at $165 \mathrm{dpp}$ which is approximately two weeks after the point where pathological changes first become histologically apparent, but well before testicular architecture breaks down completely in the AMH-Cre $\operatorname{Sox} 9^{\text {flox/flox }}$ background [18]. Affymetrix Mouse Genome 4302.0 high-density oligonucleotide GeneChips are extremely robust tools that yield highly reproducible data $[32,33]$ and complex mammalian samples are amenable to reliable analysis when examined in duplicate $[22,24,34]$. We therefore used two independent pooled samples of 90 dpp and 165 dpp testes from Sox $9^{\text {flox/flox }}$ and AMH-Cre Sox $9^{\text {flox/flox }}$ mice to prepare total- and cRNA of uniformly high quality (Additional file 1 Figure S1A and B). GeneChip hybridization patterns were normal in all cases (Additional file 1 Figure S1C) and the signals displayed the expected RNA degradation and intensity distribution profiles (Additional file 1 Figure S1D and E).

\section{Testes from Sox $9^{\text {flox/flox }}$ and AMH-Cre Sox $9^{\text {flox/flox }}$ mice show distinct mRNA concentration profiles}

We first identified 14,106 and 14,438 genes, respectively, for which signals above the threshold level of detection (5.3 $\log 2$ units corresponding to the median intensity) were obtained at $90 \mathrm{dpp}$ and $165 \mathrm{dpp}$ (Additional File 2 Table S1). We next selected genes significantly differentially expressed (2-fold change, LIMMA test with FDR adjusted $p$-value $<0.01)$ and used the k-means clustering algorithm $(n=2)$ to group them into 16 genes showing stronger signals and 7 genes showing weaker signals in the mutant samples at $90 \mathrm{dpp}$ (Figure 1A). The extremely low number of gene for which variations were found is in keeping with the lack of any detectable phenotype at the $90 \mathrm{dpp}$ control time point as compared to the $\operatorname{Sox} 9^{\text {flox/flox }}$ control. We then repeated the procedure with the $165 \mathrm{dpp}$ samples and identified 1119 genes for which we measured increased signals and 113 genes associated with decreased signals (Figure 2A). This result is consistent with the morphological changes observed in testicular tissue after the onset of dysgenesis at the age of 5 months [18].

Among the loci for which signals are stronger in the mutant, only two were found exclusively at $90 \mathrm{dpp}, 14$ were observed in both samples and 1105 were detected only at 165 dpp. Similarly, three, four and 109 genes were found to be weaker only at $90 \mathrm{dpp}$, in both samples or only at $165 \mathrm{dpp}$, respectively (Figure $1 \mathrm{~B}$ and Additional File 2 Table S1). These results show, as expected, that a substantial effect on RNA concentrations is detectable only at $165 \mathrm{dpp}$ at the onset of testicular failure.

\section{Increasing and decreasing mRNA concentrations in AMH-Cre Sox $9^{\text {flox/flox }}$ samples are associated with} different testicular cell types and biological processes

We integrated the expression signals obtained with total testis samples from So $x 9^{\text {flox/flox }}$ and AMH-Cre Sox $9^{\text {flox } /}$ flox mice with our data from enriched wild-type Sertoli cells, spermatogonia, spermatocytes, spermatids and total testis samples [22] as well as ovary samples obtained from the GEO public array data repository (Methods) [35]. We note that the experimental design allows for determining overall mRNA concentration changes between replicate samples which may or may not be due to transcriptional effects. We refer to statistically significant changes in expression values between wild-type and mutant testes alternatively as stronger 

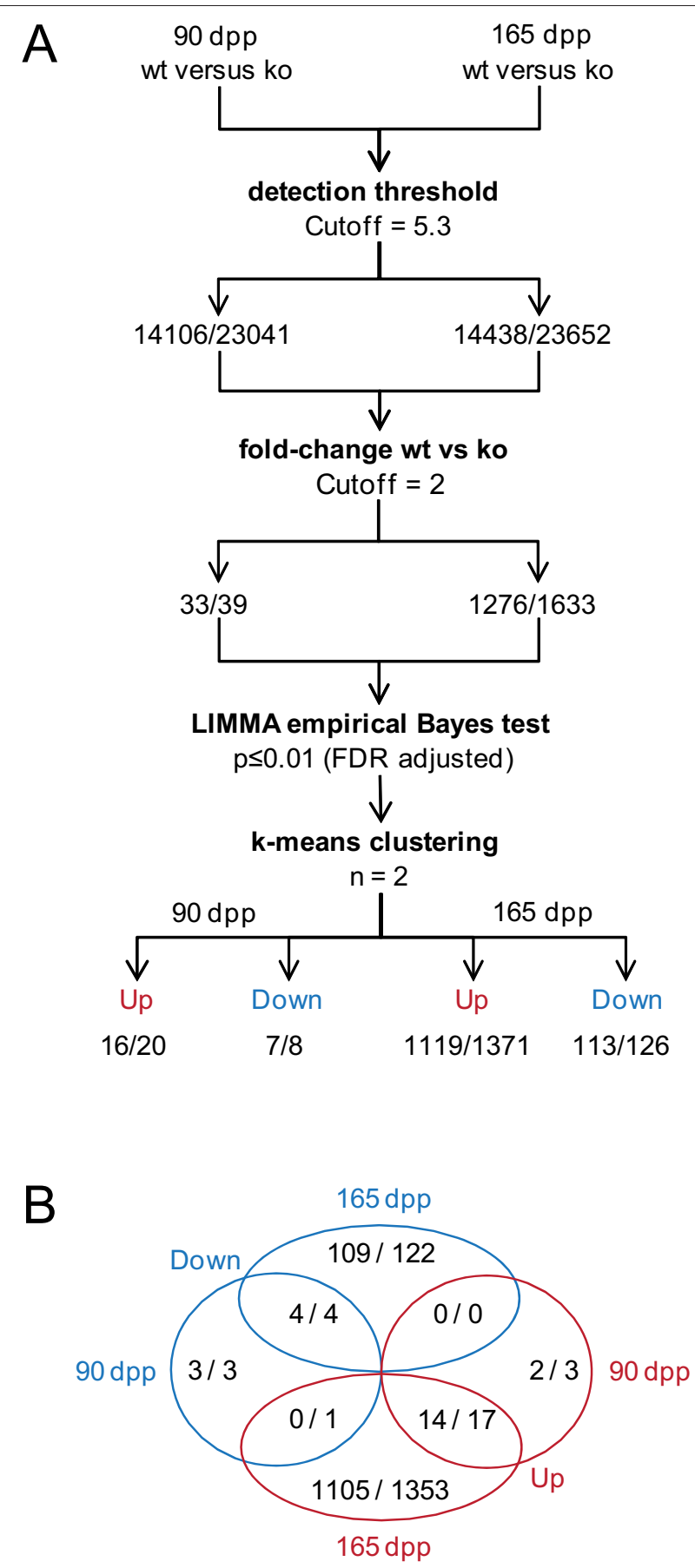

Figure 1 Gene filtration strategy and output. (A) A schematic drawing outlines the method used to identify and cluster genes showing statistically significant signal changes across the 90 and $165 \mathrm{dpp}$ time points. The numbers of genes and probe sets are given. (B) A Venn diagram summarizes the distribution of genes into up and down categories at the time points given.

(increasing) and weaker (decreasing) signals which implies that more or less mRNA, respectively, is present in the given sample.

Figure 2A shows a heatmap summarizing expression signals for two genes showing stronger signals only at $90 \mathrm{dpp}$ while no increase was found at $165 \mathrm{dpp}$ (Class 1;
Fam181b, Igf1r), 14 genes showing stronger signals at both time points (Class 2; Aqp5, C3, Ccdc80, Ildr2, Hoxd10, Lrg1, Serpina3n, Spon1, Sult1e1, Thrsp, Timp1, Tnfrsf12a, Tspan8, Wwtr1) and 1105 loci which pass our selection criteria ( $>2$-fold) for a significant signal increase only at $165 \mathrm{dpp}$ (Class 3; see Additional File 2 


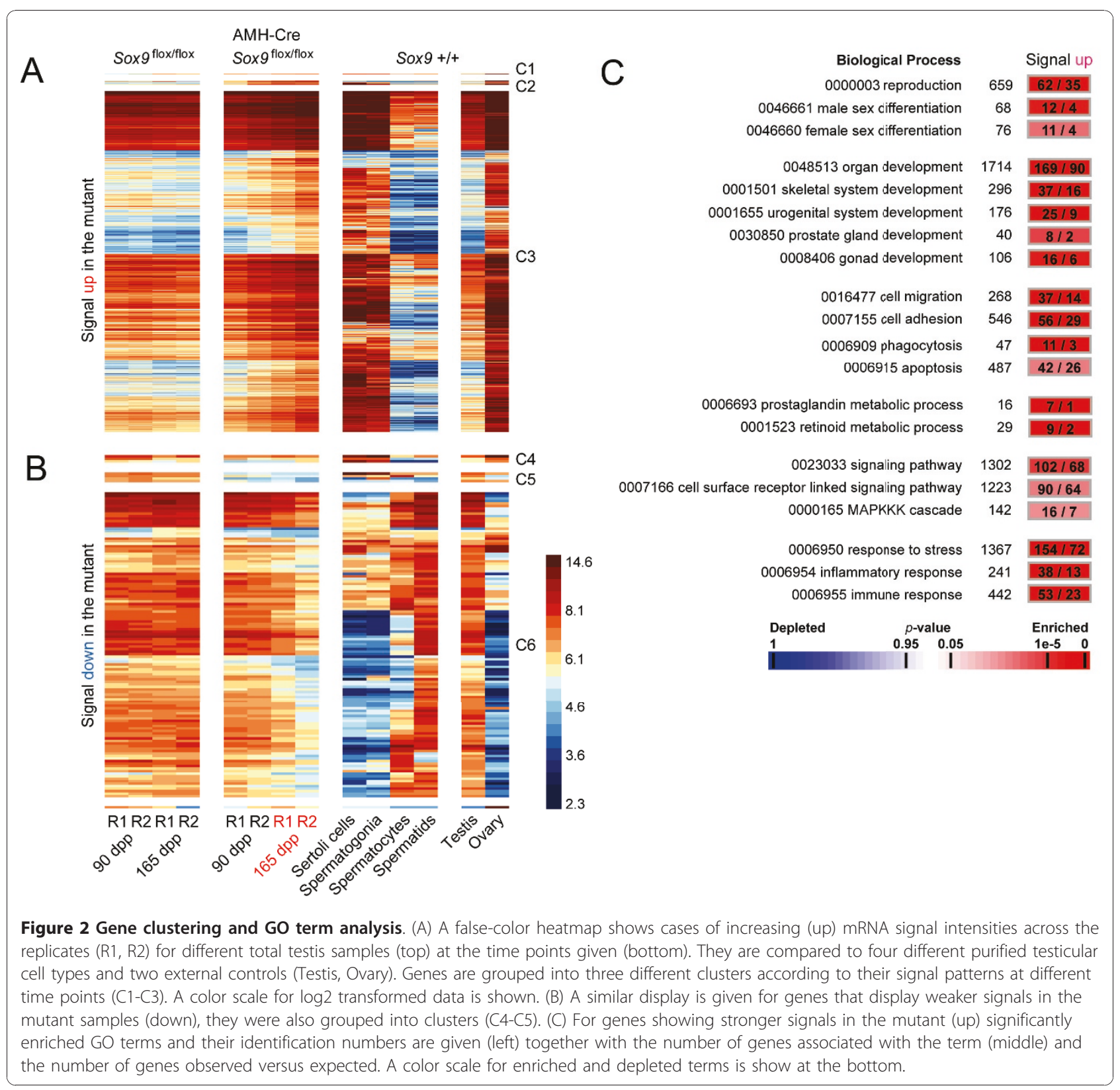

Table S1 which contains find and filtering functions to call up the complete expression data set for individual genes or groups of loci; see also GermOnline for expression data freely available for all genes represented on the Mouse Genome 4302.0 GeneChip; [36]). For genes in Class 3 we observe the strongest signals in purified somatic wild-type Sertoli cells and spermatogonia as well as ovary (Figure $2 \mathrm{~A}$ ).

Figure $2 \mathrm{~B}$ depicts the signals for three genes showing weaker signals only at $90 \mathrm{dpp}$ (Class 4; Kctd14, Schip1, LOC100044139), four cases where signals were decreased in both samples (Class 5; Clic6, Diras2, Sox6, Sox9) and
109 loci whose transcript concentrations decrease in the mutant at 165 dpp (Class 6; Additional File 2 Table S1). As opposed to the genes shown in panel A we typically find the loci to display the strongest signals in purified pachytene spermatocytes and round spermatids; these results are confirmed by strong signals in testes and mostly weak ones in ovary (Figure 2B).

We next explored the biological processes associated with groups of genes showing signal changes among the sample set by determining if these groups were statistically significantly enriched for genes bearing specific Gene Ontology (GO) terms (Methods) (Figure 2C). 
While no GO terms were found to be enriched in the group showing decreased signals, we identified several relevant processes among the genes for which stronger signals are observed in the mutant. First, as anticipated, we found Reproduction (GO:0000003, 62 observed/35 expected by chance, $p$-value: $\left.3.6 \times 10^{-5}\right)$, Male sex differentiation $\left(0046661,12 / 4,4.5 \times 10^{-4}\right)$, and Female sex differentiation $\left(0046660,11 / 4,3.8 \times 10^{-3}\right)$. A large group of genes was annotated as being involved in Organ development $\left(0048513,169 / 90,1.3 \times 10^{-15}\right)$; consistently, we find enrichment of terms relevant for bone formation and the reproductive tract such as Skeletal system development $\left(0001501,37 / 16,4.8 \times 10^{-6}\right)$ and development of the Urogenital system $\left(0001655,25 / 9,2.3 \times 10^{-5}\right)$, Prostate gland $\left(0030850,8 / 2,1.5 \times 10^{-3}\right)$, and Gonad (0008406, 16/6, $\left.3.7 \times 10^{-4}\right)$.

At the cellular level we found two terms particularly pertinent for Sertoli cell- germ cell interactions as spermatogenesis progresses: Cell migration (0016477, 37/14, $\left.3.9 \times 10^{-7}\right)$, and Cell adhesion $\left(0007155,56 / 29,8 \times 10^{-6}\right)$ while Phagocytosis $\left(0006909,11 / 3,5 \times 10^{-5}\right)$ and Apoptosis $\left(0006915,42 / 26,3.9 \times 10^{-3}\right)$ reveal extensive absorption of cellular material and programmed cell death typical for Sertoli cells and meiotic germ cells, respectively. As far as biochemical processes important for reproduction are concerned we identified metabolism of Prostaglandin $\left(0006693,7 / 1,7.6 \times 10^{-6}\right)$, and Retinoid (0001523, 9/2, $\left.1.7 \times 10^{-5}\right)$.

Interestingly, the group of genes showing increased signals includes some involved in Signaling (0023033, $\left.102 / 68,1.6 \times 10^{-4}\right)$ and notably Cell surface receptor linked signaling $\left(0007166,90 / 64,2.9 \times 10^{-3}\right)$ such as the MAPKKK cascade $\left(0000165,16 / 7,7.5 \times 10^{-3}\right)$. These signal transduction pathways play roles in similarly enriched processes such as Response to stress (0006950, $\left.154 / 72,1.6 \times 10^{-19}\right)$ and Inflammatory-, $(0006954,38 /$ $\left.13,6.2 \times 10^{-2}\right)$ as well as Immune response $(0006955$, $53 / 23,1.1 \times 10^{-7}$ ).

These results indicate that reproducible mRNA concentration changes occur in AMH-Cre Sox $9^{\text {flox/flox }}$ samples at the onset of testicular breakdown, and that the group of genes for which we find a signal increase contains more genes involved in male reproductive functions, female sex differentiation, stress response and inflammatory processes than would be expected to occur by chance. Lists of genes bearing specific GO annotations as described are available via Additional File 2 Table S1.

\section{Conserved regulatory motifs are enriched within the} promoters of genes showing signal changes in Sox $9^{\text {flox/flox }}$ versus $\mathrm{AMH}-\mathrm{Cre}$ Sox $9^{\text {flox/flox }}$ testes

To gain further insight into the regulatory processes that contribute to the RNA signature triggered by the absence of Sox9 in Sertoli cells, we first identified 202 genes for which mRNA was detectable only in mutant testes but not the normal controls. We found that the promoters of these genes - for which we find strong signals in purified Sertoli cells, spermatogonia and ovary but not in testis - were statistically significantly enriched for conserved target sites of Sox9 (Figure 3A-C, Methods). Moreover, we identified the motifs of regulators known or thought to be involved in Wnt signaling (Tcf7l2, Zbtb33/Kaiso), embryonic and post-natal development (Maf, Nfia, Pou5f1, Runx2, Tead1, Tef), steroid hormone signaling (Esr1, Nr2f2), stress response (Nfe2l2, Ppara) and immune function (Bhlhe40, Cebpa, Cebpb, Elf1, Irf8, Jun, Stat6) (Figure 3E).

We next selected 23 genes for which mRNA was detected in Sertoli cells and that showed weaker signals in AMH-Cre Sox $9^{\text {flox/flox }}$ samples to determine if they were potential direct Sox 9 targets. The majority of them showed the strongest signals in purified meiotic and post-meiotic germ-cells and among those for which the highest signals were observed in purified Sertoli cells only five $(M p b$, Tcf7l2, Acaca, Ank2 and Apbb1ip) were below the threshold level of detection in the mutant and had at least one Sox 9 binding site in their upstream promoter regions (Figure 3D). The only enriched motif identified in the group showing decreased signals in the mutant was the target site bound by the Androgen Receptor $(A r)$ which is involved in testosterone signaling (Figure $3 \mathrm{E})$.

\section{Testicular failure in AMH-Cre Sox $9^{\text {flox/flox }}$ mice is concomitant with extensive inflammatory and stress- response network activation}

To better understand the level of interconnectivity between transcription factors and target genes that responded to the Sox9 deletion we integrated the output of our analysis with published transcriptional regulatory data from TRANSFAC and TFe (Methods). We identified one large network including 14 transcription factors showing stronger signals in the AMH-Cre Sox $9^{\text {flox/flox }}$ testes and five showing weaker ones (including Sox9 itself for which, as expected, no transcript was detected) (Figure 4A). Furthermore, we found a small complex (Irf8 and $B 2 m / C y b b / H 2-D 1$ targets) and two binary interactions (Zbtb33/S100a4 and Hoxd9/Hoxd10) (Figure $4 \mathrm{~B}$ ). The interactions typically reveal concordant patterns for transcription factors and their target genes in the group of genes showing increased signals in the mutant. Factors such as Cebpb, Epas1, Irf8, and Jun are involved in controlling immunological processes often via regulating cytokine gene expression. The network data also suggest a certain level of coordination between immune-, and stress response, development (Cebpa, Fosl2, Hoxd9, Hoxd10, Maf, Nfe2l2, Nfia, Ppara) and gene expression controlled by steroid hormone receptors (Ar, Esr1, Nr2f2 and Rxra). 


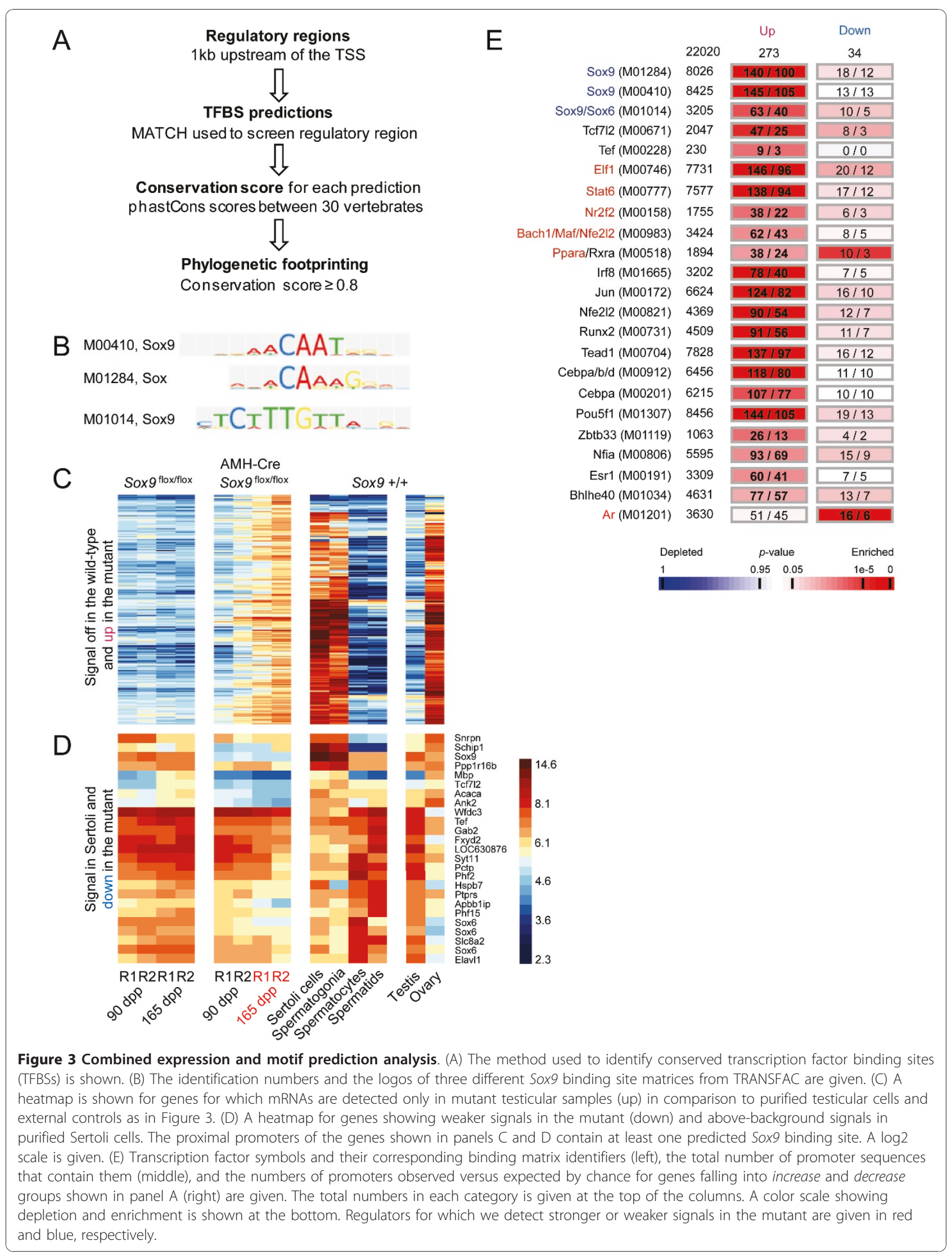




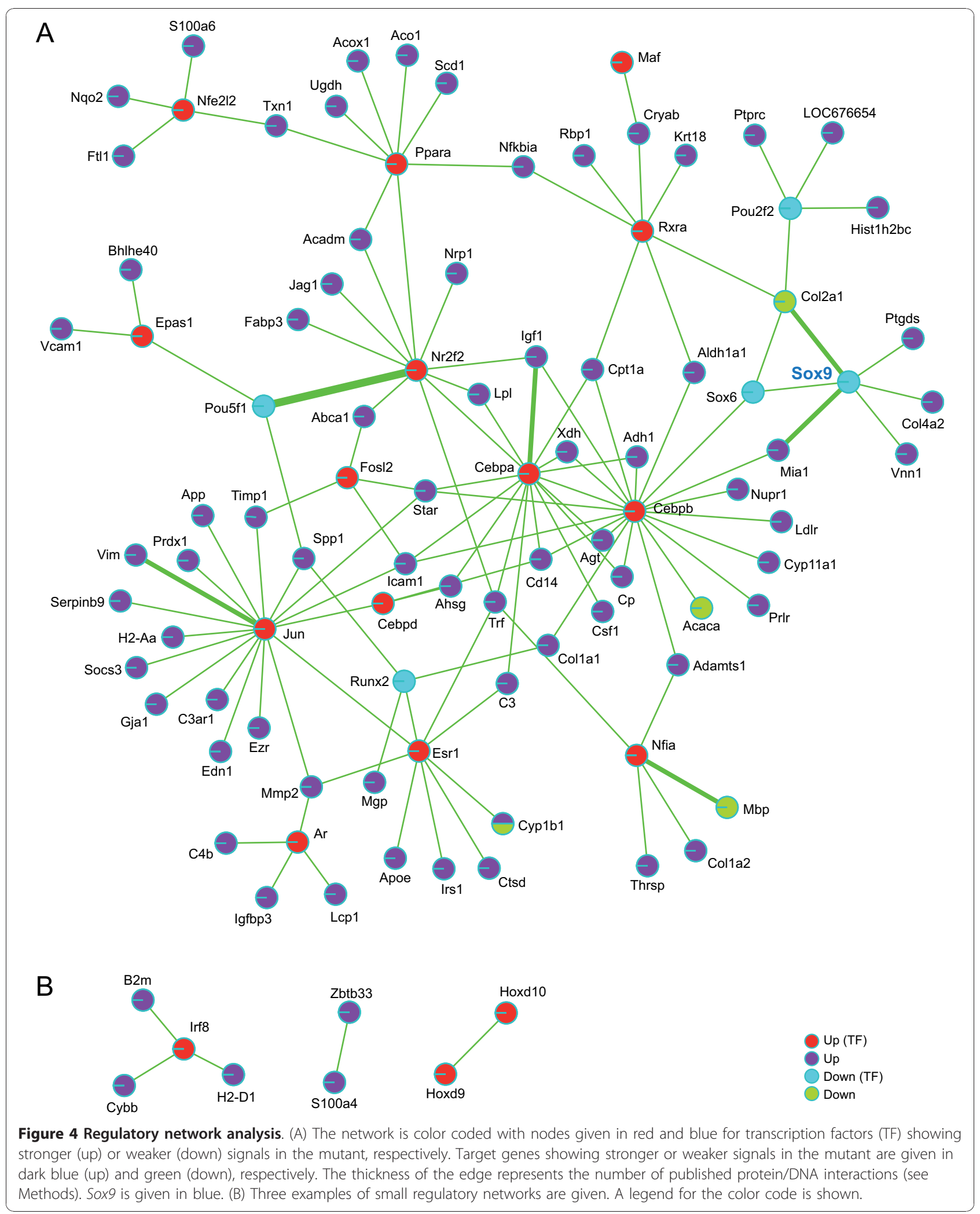


In addition to Sox9, we identified four transcription factors which displayed weaker signals in AMH-Cre Sox $9^{\text {flox/flox }}$ testes in spite of the fact that their target genes show a signal increase: Sox6 (development of the central nervous system, chondrogenesis and maintenance of cardiac and skeletal muscle cells), Pou $5 \mathrm{fl}$ (embryonic stem cell pluripotency), Pou $2 f 2$ (B-cell maturation) and Runx2 (chondrocyte-, and osteoblast differentiation).

\section{Discussion}

Targeted deletion of the Sox9 transcription factor in testicular Sertoli cells at E14.0, after the initial phase of sex determination, does not prevent spermatogenesis from being established but causes its progressive degeneration from the age of five months onwards. The phenotype includes morphological changes such as reduced testis size, loss of germ cells in approximately $30 \%$ of the tubules and an increased Leydig cell population [18]. We sought to better understand the molecular events underlying this effect by establishing whole-genome RNA concentration profiles of samples from mice bearing the Sox $9^{\text {flox/flox }}$ allele as compared to AMH-Cre Sox $9^{\text {flox/flox }}$ animals. To this end, we isolated material from both strains before (90 dpp) and after (165 dpp) the onset of testicular degeneration. Because of practical issues including small sample size and low frequency of transgenic off-spring, we analysed total testicular tissues rather than purified cell populations. In the analysis described here histological observations were combined with different types of expression-, motif prediction and gene regulation data to discern biological processes and to establish a genome-wide signature of a complex progressive male infertility phenotype. The raw data are available via the EBI's ArrayExpress repository (Methods) and normalized signals were integrated into Additional file 2 Table S1 and the GermOnline database.

Sox9 is typically (but not exclusively) involved in the transcriptional activation of its targets genes [19,37]. Therefore we first focused on the group of genes showing diminished mRNA concentrations in AMH-Cre Sox $9^{\text {flox/flox }}$ testis. Among 126 probe-sets displaying a signal decrease in the AMH-Cre Sox $9^{\text {flox/flox }}$ mutant samples we found 62 to show the strongest signals in purified meiotic and post-meiotic germ cells indicating an indirect effect since Sox9 was deleted only in Sertoli cells. Although the genes corresponding to 25 of them contained at least one match to a known Sox 9 motif in their proximal promoter region almost none of them were reliably detected in purified Sertoli cells effectively ruling them out as direct candidates (with the caveat that the purification procedure may have affected their expression). Moreover, in many cases the signals are only weaker but not abolished. We conclude that for these genes we find decreased signals most likely because of diminishing germ cell populations in the tubules of mutant testis [18].

We reasoned that direct Sox9 Sertoli target genes should display decreased signals in $90 \mathrm{dpp}$ and $165 \mathrm{dpp}$ AMH-Cre Sox $9^{\text {flox/flox }}$ mutant samples, at least one Sox 9 binding motif should be present in their proximal promoter regions and their mRNA should be detectable in purified wild-type Sertoli cells. The loci we found using these three selection criteria include Acaca (acetylCoenzyme A carboxylase alpha) which is involved in fatty acid metabolism; its deletion causes an embryonic lethal phenotype [38], $M p b$ (Myelin basic protein) which encodes a component of the myelin sheath in the central nervous system as well as other splice variants associated with diverse cellular functions [39], and $A n k 2$ (Ankyrin 2) which is known to be involved in brain and muscle development $[40,41]$. Furthermore, we identified Sox6 which is predominantly expressed in the male germline but for which mRNA is also detectable in Sertoli cells (GermOnline; [22,42]). It was demonstrated that Sox6 expression is lost in Sox9-deficient limb buds [43], that the human SOX6 promoter is bound and activated by Sox9 in chondrogenic cells [44] and that Sox6 helps Sox9 activate a target gene in cartilage [45]. It is possible that the weaker signal for Sox6 is due to diminished germ cell numbers at $165 \mathrm{dpp}$. However, we observe a two-fold signal reduction already at $90 \mathrm{dpp}$ when the germ cell content of the seminiferous tubules is unaffected. It is therefore conceivable that Sox6 plays an unexpected role in Sertoli cells and that its expression in this cell type (but not in germ cells) requires Sox9. Another potentially interesting gene we identified is $T c f 7 l 2$ (transcription factor 7-like 2) which encodes a protein involved in Wnt signaling $[46,47]$. It is known that Sox9 inhibits Wnt signaling in chondrocytes [48] and that abnormal activation of the Wnt pathway in mouse Sertoli cells leads to degeneration of tubules and infertility $[49,50]$, a phenotype reminiscent of the one reported for AMH-Cre Sox $9^{\text {flox/flox }}$ mice [18]. We speculate that perturbed $T c f 7 l 2$-dependent Wnt signaling might contribute to late-onset infertility in the absence of Sox9 in Sertoli cells.

Genes that show higher mRNA concentrations in the mutant testis or that are detectable only in pathological tissue reflect increasing cell populations (Leydig cells) and, predominantly, cellular stress. Examples include the Leydig cell markers Cyp17, Cyp11a1, Cyp21a1, and Star [51-53] or Nr2f2 [54] as well as genes that are involved in cell adhesion $(\mathrm{Cml5})$, structural components such as collagens (Col4a5, Col11a1), keratin (Krt18), metalloproteases (Adam8, Adam10, Adamts1, Adamts5) and an inhibitor of this type of enzyme (Timp1). We also identified Wnt4 which is involved in female sex determination 
[55-57] (for review see [58]); it was observed previously that the absence of Sox9 in Sertoli cells triggers derepression of genes involved in this process during preand early post-natal stages $[16,17]$. It is tempting to speculate that the phenomenon, due to dedifferentiation of mature Sertoli cells, persists until late adulthood. This is in keeping with the recent observation that a deletion of Foxl2 (the antagonist of Sox9 in female gonads) in ovarian follicle cells causes granulosa and theca cells to acquire Sertoli-, and Leydig cell-like features such as testosterone production [59] (for review, see [60]).

A potentially interesting result of our study is the strong immunological component of the RNA signature. This phenomenon is clearly reflected by the gene networks of Jun and Cebpb in particular: most of their target genes which show increased or even specific signals in AMH-Cre Sox $9^{\text {flox/flox }}$ testes (such as C3ar1, Cd44, Cd14, Cebpa, Cxcl13, H2-Aa, Icam1, Ildr2, Ly6d, Maob, Nupr1, and $\operatorname{Prdx1}$ ) are involved in immunological or inflammatory processes (see Mouse Genome Database for references). Interestingly, we also observed loci that play roles in down-regulating the immune response which likely reflects a stress response mechanism activated in increasingly damaged testicular tissue: for example, we found two serine protease inhibitors Serpinb6b (Serine (or cysteine) peptidase inhibitor, clade B, member 6B) and Serpina3n, [61], which are known to act on Granzymes A and B proteases secreted by cytotoxic T-lymphocytes $[62,63]$. Cultured human Sertoli cells - which are perhaps in a similar state of stress as Sox9-negative Sertoli cells in degenerating testicular tissue - secrete Serpina3n which was found to bind and inhibit Granzyme B, revealing a direct mechanism of Sertoli cell-dependent immunoprotection [64]. We note that Serpins are also produced by Leydig cells [65] and their strong mRNA signals may therefore at least in part be due to the proportional increase of the Leydig cell population in AMH-Cre Sox $9^{\text {flox/flox }}$ samples at $165 \mathrm{dpp}$ [18]. In this context it is interesting that Serpina5/Pci plays an important role in male reproduction since homozygous Serpina5-/- mice cannot maintain the Sertoli cell-dependent blood-testis barrier and become infertile [66]. We found that Serpina5 showed an mRNA signal increase at $165 \mathrm{dpp}$ (GermOnline, Additional File 1) which may in part reflect a compensatory mechanism stemming the disruption of seminiferous tubules. Moreover, we observed strongly elevated mRNA concentrations for Spp1 (Secreted phosphoprotein 1) a protein thought to play a protective role by inhibiting apoptosis and by modulating the immune response [67].

Finally, it is remarkable that some mouse genes that display increased mRNA concentrations in mutant male gonads have human orthologs that appear to be up- regulated in the testes of different types of infertile patients showing various degrees of spermatogenic failure [68]. This group of loci includes Adamts5 (a disintegrin-like metallopeptidase with thrombospondin type 1 motif, 5; involved in osteoarthritis, [69]), Clec2b (C-type lectin domain family 1 involved in platelet activation and aggregation, [70]), Ctsc (Cathepsin $C$ required for the activation of Granzymes A and B, [71]), Ldlr (Low density lipoprotein receptor involved in cholesterol homeostasis, induced by inflammation, [72]), and Samd9l (Sterile alpha motif domain containing 9-like involved in cytokine signaling [73]). We note that these genes are mostly involved in immunological phenomena.

\section{Conclusions}

This study aimed at establishing a genome-wide mRNA signature associated with Sertoli cell-specific deletion of the Sox 9 transcription factor to better understand the molecular events that are concomitant with - but not causative of - testicular failure. Our results suggest that Sox 9 is required in Sertoli cells to prevent sex reversal until late adulthood and that AMH-Cre Sox $9^{\text {flox/flox }}$ mice are a potentially useful model system to study testicular dysgenesis syndromes [74] and inflammatory processes that might ultimately contribute to the formation of malignant tumors [68]. The data pave the way for more detailed histological examinations of both the Sox 9 mutant mouse model and patients presenting with progressive testicular failure to confirm at the protein level what our microarray study has revealed at the mRNA level.

\section{Additional material}

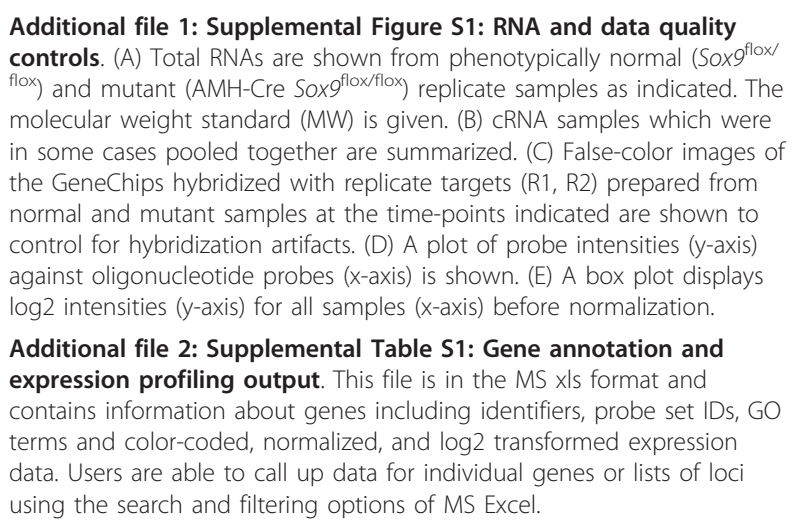

Acknowledgements

We thank B. Jégou for critical reading of the manuscript, $H$. Scherthan and J. Moore for stimulating discussions and O. Collin (IRISA, GenOuest bioinformatics platform) for MIMAS and GermOnline system administration. A. Lardenois was supported by an Inserm Young Investigator fellowship and INERIS. This work was supported by Deutsche Forschungsgemeinschaft grant Sche 195/15 awarded to G. Scherer and by Inserm Avenir grant R07216NS awarded to M. Primig. 


\section{Author details}

'Inserm, U625, Université de Rennes 1, IFR140, Rennes, F-35042, France. ${ }^{2}$ Institute of Human Genetics, University of Freiburg, Freiburg, D-79106, Germany. ${ }^{3}$ Biozentrum, University of Basel, Basel, CH-4056, Switzerland. ${ }^{4}$ Departamento de Genética e Instituto de Biotecnología, University of Granada, Granada, Spain

\section{Authors' contributions}

$\mathrm{AL}$ and $\mathrm{FC}$ analysed and interpreted expression, promoter motif prediction and regulatory network data, FB prepared the testicular samples, PD produced and quality controlled raw microarray data, GS designed research, MP interpreted data and wrote the manuscript. All authors read and approved the manuscript.

\section{Competing interests}

The authors declare that they have no competing interests.

Received: 11 November 2010 Accepted: 23 December 2010 Published: 23 December 2010

\section{References}

1. Sekido R, Lovell-Badge R: Sex determination involves synergistic action of SRY and SF1 on a specific Sox9 enhancer. Nature 2008, 453(7197):930-934

2. Sekido R, Lovell-Badge R: Sex determination and SRY: down to a wink and a nudge? Trends Genet 2009, 25(1):19-29.

3. Gordon CT, Tan TY, Benko S, Fitzpatrick D, Lyonnet S, Farlie PG: Long-range regulation at the SOX9 locus in development and disease. J Med Genet 2009, 46(10):649-656

4. Sekido R, Bar I, Narvaez V, Penny G, Lovell-Badge R: SOX9 is up-regulated by the transient expression of SRY specifically in Sertoli cell precursors. Dev Biol 2004, 274(2):271-279.

5. Kent J, Wheatley SC, Andrews JE, Sinclair AH, Koopman P: A male-specific role for SOX9 in vertebrate sex determination. Development 1996, 122(9):2813-2822.

6. Morais da Silva S, Hacker A, Harley V, Goodfellow P, Swain A, LovellBadge R: Sox9 expression during gonadal development implies a conserved role for the gene in testis differentiation in mammals and birds. Nat Genet 1996, 14(1):62-68.

7. Petersen C, Soder O: The sertoli cell-a hormonal target and 'super' nurse for germ cells that determines testicular size. Horm Res 2006, 66(4):153-161.

8. Griswold MD: The central role of Sertoli cells in spermatogenesis. Semin Cell Dev Biol 1998, 9(4):411-416.

9. Gasca S, Canizares J, De Santa Barbara P, Mejean C, Poulat F, Berta P, BoizetBonhoure B: A nuclear export signal within the high mobility group domain regulates the nucleocytoplasmic translocation of SOX9 during sexual determination. Proc Natl Acad Sci USA 2002, 99(17):11199-11204.

10. Malki S, Nef S, Notarnicola C, Thevenet L, Gasca S, Mejean C, Berta P, Poulat F, Boizet-Bonhoure B: Prostaglandin D2 induces nuclear import of the sex-determining factor SOX9 via its CAMP-PKA phosphorylation. EMBO J 2005, 24(10):1798-1809.

11. Love JJ, Li X, Case DA, Giese K, Grosschedl R, Wright PE: Structural basis for DNA bending by the architectural transcription factor LEF-1. Nature 1995, 376(6543):791-795.

12. Harley VR, Clarkson MJ, Argentaro A: The molecular action and regulation of the testis-determining factors, SRY (sex-determining region on the $Y$ chromosome) and SOX9 [SRY-related high-mobility group (HMG) box 9]. Endocr Rev 2003, 24(4):466-487.

13. Foster JW, Dominguez-Steglich MA, Guioli S, Kwok C, Weller PA, Stevanovic M, Weissenbach J, Mansour S, Young ID, Goodfellow PN, et al: Campomelic dysplasia and autosomal sex reversal caused by mutations in an SRY-related gene. Nature 1994, 372(6506):525-530.

14. Wagner T, Wirth J, Meyer J, Zabel B, Held M, Zimmer J, Pasantes J, Bricarelli FD, Keutel J, Hustert E, et al: Autosomal sex reversal and campomelic dysplasia are caused by mutations in and around the SRYrelated gene SOX9. Cell 1994, 79(6):1111-1120.

15. Bi W, Deng JM, Zhang Z, Behringer RR, de Crombrugghe B: Sox9 is required for cartilage formation. Nat Genet 1999, 22(1):85-89.
16. Barrionuevo F, Bagheri-Fam S, Klattig J, Kist R, Taketo MM, Englert C, Scherer G: Homozygous inactivation of Sox 9 causes complete $X Y$ sex reversal in mice. Biol Reprod 2006, 74(1):195-201.

17. Chaboissier MC, Kobayashi A, Vidal VI, Lutzkendorf S, van de Kant HJ, Wegner M, de Rooij DG, Behringer RR, Schedl A: Functional analysis of Sox8 and Sox9 during sex determination in the mouse. Development 2004, 131(9):1891-1901.

18. Barrionuevo F, Georg I, Scherthan H, Lecureuil C, Guillou F, Wegner M, Scherer $\mathrm{G}$ : Testis cord differentiation after the sex determination stage is independent of Sox9 but fails in the combined absence of Sox9 and Sox8. Dev Biol 2009, 327(2):301-312.

19. Barrionuevo F, Scherer G: SOX E genes: SOX9 and SOX8 in mammalian testis development. Int J Biochem Cell Biol 2009, 42(3):433-436.

20. Kist $R$, Schrewe $H$, Balling $R$, Scherer $G$ : Conditional inactivation of Sox9: a mouse model for campomelic dysplasia. Genesis 2002, 32(2):121-123.

21. Lecureuil C, Fontaine I, Crepieux P, Guillou F: Sertoli and granulosa cellspecific Cre recombinase activity in transgenic mice. Genesis 2002, 33(3):114-118.

22. Chalmel F, Rolland AD, Niederhauser-Wiederkehr $C$, Chung SS, Demougin $P$, Gattiker A, Moore J, Patard JJ, Wolgemuth DJ, Jegou B, et al: The conserved transcriptome in human and rodent male gametogenesis. Proc Natl Acad Sci USA 2007, 104(20):8346-8351.

23. Chalmel F, Primig M: The Annotation, Mapping, Expression and Network (AMEN) suite of tools for molecular systems biology. BMC Bioinformatics 2008, 9:86.

24. Schlecht $U$, Demougin $P$, Koch $R$, Hermida $L$, Wiederkehr $C$, Descombes $P$, Pineau $C$, Jegou B, Primig M: Expression profiling of mammalian male meiosis and gametogenesis identifies novel candidate genes for roles in the regulation of fertility. Mol Biol Cell 2004, 15(3):1031-1043.

25. Matys V, Kel-Margoulis OV, Fricke E, Liebich I, Land S, Barre-Dirrie A, Reuter I, Chekmenev D, Krull M, Hornischer $\mathrm{K}$, et al: TRANSFAC and its module TRANSCompel: transcriptional gene regulation in eukaryotes. Nucleic Acids Res 2006, , 34 Database: D108-110.

26. Rhead B, Karolchik D, Kuhn RM, Hinrichs AS, Zweig AS, Fujita PA, Diekhans M, Smith KE, Rosenbloom KR, Raney BJ, et al: The UCSC Genome Browser database: update 2010. Nucleic Acids Res 2010, 38 Database: D613-619.

27. Kel AE, Gossling E, Reuter I, Cheremushkin E, Kel-Margoulis OV, Wingender E: MATCH: A tool for searching transcription factor binding sites in DNA sequences. Nucleic Acids Res 2003, 31(13):3576-3579.

28. Wasserman WW, Palumbo M, Thompson W, Fickett JW, Lawrence CE: Human-mouse genome comparisons to locate regulatory sites. Nat Genet 2000, 26(2):225-228.

29. Siepel A, Bejerano G, Pedersen JS, Hinrichs AS, Hou M, Rosenbloom K, Clawson H, Spieth J, Hillier LW, Richards S, et al: Evolutionarily conserved elements in vertebrate, insect, worm, and yeast genomes. Genome Res 2005, 15(8):1034-1050.

30. Parkinson H, Kapushesky M, Kolesnikov N, Rustici G, Shojatalab M, Abeygunawardena N, Berube H, Dylag M, Emam I, Farne A, et al: ArrayExpress update-from an archive of functional genomics experiments to the atlas of gene expression. Nucleic Acids Res 2009, , 37 Database: D868-872.

31. Gattiker A, Niederhauser-Wiederkehr C, Moore J, Hermida L, Primig M: The GermOnline cross-species systems browser provides comprehensive information on genes and gene products relevant for sexual reproduction. Nucleic Acids Res 2007, , 35 Database: D457-462.

32. Chu TM, Deng S, Wolfinger R, Paules RS, Hamadeh HK: Cross-site comparison of gene expression data reveals high similarity. Environ Health Perspect 2004, 112(4):449-455.

33. Auer $\mathrm{H}$, Newsom DL, Kornacker K: Expression Profiling Using Affymetrix GeneChip Microarrays. Methods Mol Biol 2009, 509:35-46.

34. Wrobel G, Primig M: Mammalian male germ cells are fertile ground for expression profiling of sexual reproduction. Reproduction 2005, 129(1):1-7.

35. Barrett T, Troup DB, Wilhite SE, Ledoux P, Evangelista C, Kim IF, Tomashevsky M, Marshall KA, Phillippy KH, Sherman PM, et al: NCBI GEO: archive for functional genomics data sets-10 years on. Nucleic Acids Res 2010.

36. Lardenois A, Gattiker A, Collin O, Chalmel F, Primig M: GermOnline 4.0 is a genomics gateway for germline development, meiosis and the mitotic cell cycle. Database (Oxford) 2010, baq030. 
37. Maclean JA, Wilkinson MF: Gene regulation in spermatogenesis. Curr Top Dev Biol 2005, 71:131-197.

38. Abu-Elheiga L, Matzuk MM, Kordari P, Oh W, Shaikenov T, Gu Z, Wakil SJ: Mutant mice lacking acetyl-CoA carboxylase 1 are embryonically lethal. Proc Natl Acad Sci USA 2005, 102(34):12011-12016.

39. Campagnoni AT, Skoff RP: The pathobiology of myelin mutants reveal novel biological functions of the MBP and PLP genes. Brain Pathol 2001, 11(1):74-91.

40. Scotland $P$, Zhou $D$, Benveniste $H$, Bennett $V$ : Nervous system defects of AnkyrinB (-/-) mice suggest functional overlap between the cell adhesion molecule L1 and 440-kD AnkyrinB in premyelinated axons. J Cell Biol 1998, 143(5):1305-1315.

41. Mohler PJ, Schott JJ, Gramolini AO, Dilly KW, Guatimosim S, duBell WH, Song LS, Haurogne K, Kyndt F, Ali ME, et al: Ankyrin-B mutation causes type 4 long-QT cardiac arrhythmia and sudden cardiac death. Nature 2003, 421(6923):634-639.

42. Connor F, Wright E, Denny P, Koopman P, Ashworth A: The Sry-related HMG box-containing gene Sox 6 is expressed in the adult testis and developing nervous system of the mouse. Nucleic Acids Res 1995, 23(17):3365-3372.

43. Akiyama H, Chaboissier MC, Martin JF, Schedl A, de Crombrugghe B: The transcription factor Sox9 has essential roles in successive steps of the chondrocyte differentiation pathway and is required for expression of Sox5 and Sox6. Genes Dev 2002, 16(21):2813-2828.

44. Ikeda T, Saito T, Ushita M, Yano F, Kan A, Itaka K, Moro T, Nakamura K, Kawaguchi $\mathrm{H}$, Chung UI: Identification and characterization of the human SOX6 promoter. Biochem Biophys Res Commun 2007, 357(2):383-390.

45. Han Y, Lefebvre V: L-Sox5 and Sox6 drive expression of the aggrecan gene in cartilage by securing binding of Sox 9 to a far-upstream enhancer. Mol Cell Biol 2008, 28(16):4999-5013.

46. Weise A, Bruser K, Elfert S, Wallmen B, Wittel Y, Wohrle S, Hecht A: Alternative splicing of Tcf7/2 transcripts generates protein variants with differential promoter-binding and transcriptional activation properties at Wnt/beta-catenin targets. Nucleic Acids Res 2010, 38(6):1964-1981.

47. Faro A, Boj SF, Ambrosio R, van den Broek O, Korving J, Clevers H: T-cell factor 4 (tcf7/2) is the main effector of Wnt signaling during zebrafish intestine organogenesis. Zebrafish 2009, 6(1):59-68.

48. Topol L, Chen W, Song H, Day TF, Yang Y: Sox9 inhibits Wnt signaling by promoting beta-catenin phosphorylation in the nucleus. I Biol Chem 2009, 284(5):3323-3333.

49. Boyer A, Hermo L, Paquet M, Robaire B, Boerboom D: Seminiferous tubule degeneration and infertility in mice with sustained activation of WNT/ CTNNB1 signaling in sertoli cells. Biol Reprod 2008, 79(3):475-485.

50. Tanwar PS, Kaneko-Tarui T, Zhang L, Rani P, Taketo MM, Teixeira J: Constitutive WNT/beta-catenin signaling in murine Sertoli cells disrupts their differentiation and ability to support spermatogenesis. Biol Reprod 2009, 82(2):422-432.

51. Laurich VM, Trbovich AM, O'Neill FH, Houk CP, Sluss PM, Payne AH, Donahoe PK, Teixeira J: Mullerian inhibiting substance blocks the protein kinase A-induced expression of cytochrome p450 17alpha-hydroxylase/C (17-20) lyase mRNA in a mouse Leydig cell line independent of CAMP responsive element binding protein phosphorylation. Endocrinology 2002, 143(9):3351-3360.

52. Hu L, Monteiro A, Johnston H, King P, O'Shaughnessy PJ: Expression of Cyp21a1 and Cyp11b1 in the fetal mouse testis. Reproduction 2007, 134(4):585-591.

53. Kostic TS, Stojkov NJ, Janjic MM, Andric SA: Structural complexity of the testis and PKG I/StAR interaction regulate the Leydig cell adaptive response to repeated immobilization stress. Int J Androl 2009, 33(5):717-729.

54. Qin J, Tsai MJ, Tsai SY: Essential roles of COUP-TFII in Leydig cell differentiation and male fertility. PLoS One 2008, 3(9):e3285.

55. Vainio S, Heikkila M, Kispert A, Chin N, McMahon AP: Female development in mammals is regulated by Wnt-4 signalling. Nature 1999, 397(6718):405-409.

56. Ottolenghi C, Pelosi E, Tran J, Colombino M, Douglass E, Nedorezov T, Cao A, Forabosco A, Schlessinger D: Loss of Wnt4 and Foxl2 leads to female-to-male sex reversal extending to germ cells. Hum Mol Genet 2007, 16(23):2795-2804.
57. Boyer A, Lapointe E, Zheng X, Cowan RG, Li H, Quirk SM, DeMayo FJ, Richards JS, Boerboom D: WNT4 is required for normal ovarian follicle development and female fertility. FASEB J 2010, 24(8):3010-3025.

58. Bernard P, Harley VR: Wnt4 action in gonadal development and sex determination. Int J Biochem Cell Biol 2007, 39(1):31-43.

59. Uhlenhaut NH, Jakob S, Anlag K, Eisenberger T, Sekido R, Kress J, Treier AC, Klugmann C, Klasen C, Holter NI, et al: Somatic sex reprogramming of adult ovaries to testes by FOXL2 ablation. Cell 2009, 139(6):1130-1142.

60. Veitia RA: FOXL2 versus SOX9: a lifelong "battle of the sexes". Bioessays 2010, 32(5):375-380.

61. Charron Y, Madani R, Nef S, Combepine C, Govin J, Khochbin S, Vassalli JD: Expression of serpinb6 serpins in germ and somatic cells of mouse gonads. Mol Reprod Dev 2006, 73(1):9-19.

62. Heutinck KM, ten Berge IJ, Hack CE, Hamann J, Rowshani AT: Serine proteases of the human immune system in health and disease. Mol Immunol 2010, 47(11-12):1943-1955.

63. Kaiserman D, Bird PI: Control of granzymes by serpins. Cell Death Differ 2009, 17(4):586-595.

64. Sipione S, Simmen KC, Lord SJ, Motyka B, Ewen C, Shostak I, Rayat GR, Dufour JM, Korbutt GS, Rajotte RV, et al: Identification of a novel human granzyme B inhibitor secreted by cultured sertoli cells. J Immunol 2006, 177(8):5051-5058.

65. Odet F, Verot A, Le Magueresse-Battistoni B: The mouse testis is the source of various serine proteases and serine proteinase inhibitors (SERPINs): Serine proteases and SERPINs identified in Leydig cells are under gonadotropin regulation. Endocrinology 2006, 147(9):4374-4383.

66. Uhrin P, Dewerchin M, Hilpert M, Chrenek P, Schofer C, ZechmeisterMachhart M, Kronke G, Vales A, Carmeliet P, Binder BR, et al: Disruption of the protein $C$ inhibitor gene results in impaired spermatogenesis and male infertility. J Clin Invest 2000, 106(12):1531-1539.

67. Denhardt DT, Giachelli CM, Rittling SR: Role of osteopontin in cellular signaling and toxicant injury. Annu Rev Pharmacol Toxicol 2001, 41:723-749.

68. Spiess AN, Feig C, Schulze W, Chalmel F, Cappallo-Obermann H, Primig M, Kirchhoff C: Cross-platform gene expression signature of human spermatogenic failure reveals inflammatory-like response. Hum Reprod 2007, 22(11):2936-2946.

69. Bondeson J, Wainwright S, Hughes C, Caterson B: The regulation of the ADAMTS4 and ADAMTS5 aggrecanases in osteoarthritis: a review. Clin Exp Rheumatol 2008, 26(1):139-145.

70. Bertozzi CC, Schmaier AA, Mericko P, Hess PR, Zou Z, Chen M, Chen CY, Xu B, Lu MM, Zhou D, et al: Platelets regulate lymphatic vascular development through CLEC-2-SLP-76 signaling. Blood 2010, 116(4):661-670.

71. Pham CT, Ley TJ: Dipeptidyl peptidase I is required for the processing and activation of granzymes A and B in vivo. Proc Natl Acad Sci USA 1999, 96(15):8627-8632.

72. Ohashi R, Mu H, Yao Q, Chen C: Cellular and molecular mechanisms of atherosclerosis with mouse models. Trends Cardiovasc Med 2004 14(5):187-190.

73. Pappas DJ, Coppola G, Gabatto PA, Gao F, Geschwind DH, Oksenberg JR, Baranzini SE: Longitudinal system-based analysis of transcriptional responses to type I interferons. Physiol Genomics 2009, 38(3):362-371

74. Wohlfahrt-Veje C, Main KM, Skakkebaek NE: Testicular dysgenesis syndrome: foetal origin of adult reproductive problems. Clin Endocrinol (Oxf) 2009, 71(4):459-465.

doi:10.1186/1477-7827-8-154

Cite this article as: Lardenois et al:: Profiling spermatogenic failure in adult testes bearing Sox9-deficient Sertoli cells identifies genes involved in feminization, inflammation and stress. Reproductive Biology and Endocrinology 2010 8:154. 